\title{
BIODEGRADASI ZAT WARNA ACID ORANGE 7 MENGGUNAKAN ENZIM JAMUR TIRAM PUTIH (PLEUROTUS OSTREATUS)
}

\author{
Hasri, Sudding, Achmad Amiruddin* \\ Jurusan Kimia, FMIPA \\ Universitas Negeri Makassar \\ *e-mail: aachmad007@gmail.com
}

Received 1 April 2018

Accepted 2 Mei 2018

\begin{abstract}
Abstrak
Pewarna sintetik banyak digunakan dalam industri tekstil karena sifatnya lebih stabil, mudah diperoleh dan murah, namun limbahnya sulit terdegradasi, sehingga dapat menyebabkan kontaminan di perairan. Salah satu metode alternatif dan ramah lingkungan yang dapat digunakan untuk mendegradasi limbah zat warna sebelum dibuang ke perairan adalah dengan memanfaatkan mikroorganisme sebagai agen pendegradasi. Penelitian ini bertujuan untuk mengetahui kemampuan enzim jamur P.ostreatus dalam mendegradasi zat warna acid orange 7 berdasarkan variasi waktu degradasi. Hasil penelitian menunjukkan bahwa enzim jamur P.ostreatus mampu mendegradasi acid orange 7 hingga 59,36\%.
\end{abstract}

Katakunci: degradasi, acid orange 7, jamur P.ostreatus

\begin{abstract}
Synthetic dyes is most be used in the textile industry because it is stable, easy to obtain, and cheap, the waste, however, is difficult to degrade, so it can cause contaminants in the waters and disrupt the aesthetics of water bodies. One of the alternative and environmentallyfriendly methods that can be used to degrade dyestuff waste prior to discharge into the waters is by utilizing microorganisms as degrading agents. Therefore, this study aims to determine the ability of P.ostreatus fungus enzymes in degrading acid orange dyes 7 based on the variation of degradation time. The results showed that P.ostreatus fungus enzyme was able to degrade the orange acid 7 until $59.36 \%$
\end{abstract}

Keywords: degradation, acid orange 7, white oyster mushroom (P.ostreatus)

\section{Pendahuluan}

Pertambahan jumlah industri di Indonesia mengakibatkan meningkatnya bahan pencemar limbah yang dihasilkan industri tersebut. Salah satu industri yang mampu menyebabkan pencemaran lingkungan yaitu industri tekstil, terutama pada limbah cairnya yang berasal dari cairan hasil proses pewarnaan dan proses pencelupan serta proses-proses lain yang berhubungan dengan proses industri tersebut.
Umumnya, pewarna yang digunakan dalam industri tekstil merupakan pewarna sintetik. Salah satu jenis pewarna sintetik yang digunakan pada industri tekstil adalah jenis zat warna azo yaitu acid orange 7 , zat warna ini merupakan salah satu jenis zat warna yang digunakan dalam proses pencelupan bahan tekstil. Zat warna ini larut dalam air, sehingga mampu mengakibatkan masalah lingkungan yaitu dapat menurunkan kualitas air dan dapat menjadi ancaman bagi masyarakat di sekitarnya mengingat 
pewarna azo dan hasil metabolitnya toksik dan bersifat karsinogenik (Chung, et al., 1981). Sehingga perlu penanganan terlebih dahulu sebelum limbah tersebut dibuang ke perairan.

Pengolahan zat warna dalam limbah cair tekstil dapat dilakukan secara kimia, fisika dan biologi. Pengolahan air limbah tekstil secara kimia dan fisika cukup efektif untuk menghilangkan warna, akan tetapi tidak efisien dari segi biaya dan pemakaian bahan kimia serta menimbulkan sludge yang banyak (Sastrawidana, dkk., 2012). Oleh karena itu, diperlukan metode yang ramah lingkungan, efisien dan murah yaitu secara biologi yang disebut biodegradasi. Biodegradasi adalah salah satu proses menurunkan tingkat kontaminan menjadi bahan yang kurang atau tidak beracun dalam tanah, air dan lingkungan dengan menggunakan mikroorganisme (jamur atau bakteri) sebagai agen pendegradasi (Ulfi, dkk., 2014).

Jamur mampu mendegradasi komponen warna yang bersifat toksik karena mempunyai kemampuan untuk transformasi, yaitu merubah dari bahan kimia berbahaya pada limbah menjadi bentuk yang kurang atau tidak berbahaya (Awaluddin, dkk., 2001). Salah satu jenis jamur yang mampu mendegradasi zat warna yaitu jamur tiram putih (P.ostreatus), jamur ini memproduksi enzim ektraseluler seperti enzim lakase (Hatakka, 2001). Enzim lakase mampu mendegradasi substrat fenolik dan nonfenolik melalui proses oksidasi. Potensi strategis penggunaan enzim ini adalah proses perombakannya sampai pada mineralisasi menghasilkan zat tidak toksik (Katia, et al., 2006)

Berdasarkan uraian di atas, maka penelitian ini bertujuan untuk mengetahui kemampuan enzim jamur P.ostreatus dalam mendegradasi zat warna acid orange 7 berdasarkan variasi waktu degradasi.

\section{Metode Penelitian}

Alat dan bahan

Alat-alat yang digunakan dalam penelitian ini adalah Spektrofotometer UV-Vis, pH-pen, sentrifuge, oven, autoclave, neraca analitik, hotplate, botol kaca, inkubator, cawan petri, kawat ose dan skalpel.

Bahan-bahan yang digunakan dalam penelitian ini adalah bibit jamur tiram putih (P.ostreatus), aquabides, alkohol $70 \%$, pewarna acid orange 7 , natrium nitrat $\left(\mathrm{NaNO}_{3}\right)$, kalium klorida $(\mathrm{KCl})$, ferro-sulfat heptahidrat $\left(\mathrm{FeSO}_{4} \cdot 7 \mathrm{H}_{2} \mathrm{O}\right)$, buffer fosfat $\mathrm{pH}$ 6, kalium dihidrogen posfat $\left(\mathrm{KH}_{2} \mathrm{PO}_{4}\right)$, magnesium sulfat heptahidrat $\left(\mathrm{MgSO}_{4} .7 \mathrm{H}_{2} \mathrm{O}\right)$, PDA (Potato Dextrose Agar), dan sukrosa.

\section{Prosedur penelitian}

Produksi enzim jamur P.ostreatus

Inokulum Jamur yang telah tumbuh pada media PDA diinokulasi dalam media nutrisi secara aseptis. Campuran ditutup dengan kapas dan dikocok menggunakan shaker dengan kecepatan $120 \mathrm{rpm}$ selama 7 hari pada suhu ruang. Setelah proses produksi enzim selesai, selanjutnya dilakukan sentrifugasi dengan kecepatan 6000 rpm selama 15 menit. Hasil sentrifugasi kemudian dipisahkan antara padatan dan filtrat. Filtrat ekstrak enzim yang diperoleh digunakan sebagai agen pendegradasi

\section{Biodegradasi zat warna acid orange 7}

Biodegradasi zat warna acid orange 7 dilakukan dengan menambahkan sebanyak $3 \mathrm{~mL}$ zat warna acid orange 7 dengan konsentrasi $50 \mathrm{ppm}$ ke dalam botol kaca yang berisi sebanyak $9 \mathrm{~mL}$ ekstrak enzim. Selanjutnya ditutup dan diinkubasi pada suhu ruang dengan variasi waktu 24, 48, 72, 96, 120 dan 144 jam. Setelah diinkubasi, selanjutnya diukur absorbansi sampel menggunakan spektrofotometer UV-Vis pada panjang gelombang $479 \mathrm{~nm}$.

Kemampuan enzim dalam mendegradasi zat warna acid orange 7 
ditentukan dengan cara membandingkan konsentrasi zat warna yang terdegradasi terhadap konsentrasi zat warna awal dan dikalikan $100 \%$. Secara matematis persentase degradasi $(\% \mathrm{D})$ dapat dihitung dengan menggunakan rumus persamaan 1 dengan $\mathrm{C}_{\mathrm{a}}$ dan $\mathrm{C}_{\mathrm{s}}$ adalah konsentrasi awal dan akhir

\section{Hasil dan Pembahasan}

Penumbuhan jamur P.ostreatus dilakukan dengan menggunakan media PDA yang bertujuan untuk memperoleh miselium jamur. Miselium jamur yang tumbuh pada PDA kemudian ditransfer secara aseptik ke dalam media Czapex cair dan diinkubasi pada suhu ruang. Hal ini dilakukan untuk memperoleh suspensi jamur P.ostreatus. Media Czapex cair mengalami perubahan dari keruh menjadi berwarna kuning. Warna kuning yang ditimbulkan selama proses penumbuhan jamur disebabkan karena ekskresi enzim ekstraseluler oleh jamur tersebut ${ }^{[7]}$. Supernatan disentrifuge sehingga diperoleh ekstrak enzim jamur P.ostreatus yang disajikan pada Gambar 1.

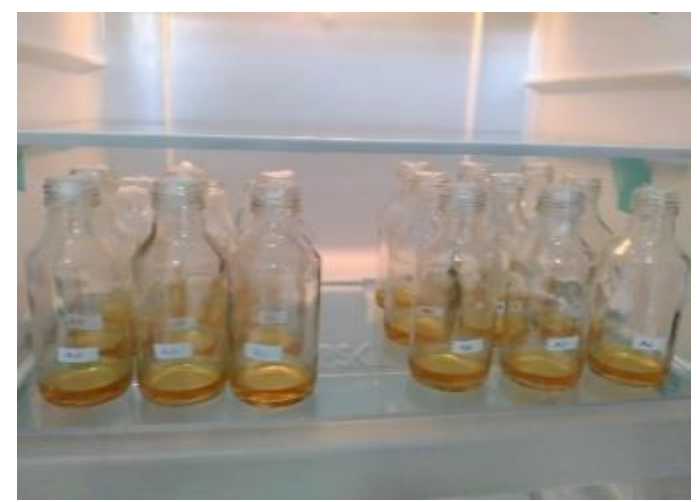

Gambar 1. Ekstrak enzim jamur P.ostreatus

Biodegradasi zat warna acid orange 7 dilakukan dengan mereaksikan ekstrak enzim dengan zat warna acid orange 7. Konsentrasi acid orange 7 yang tersisa diamati dengan alat Spektrofotometer UV-Vis pada panjang gelombang $479 \mathrm{~nm}$. Hasil penelitian menunjukkan bahwa waktu kontak optimum enzim dalam mendegradasi zat warna acid orange 7 yaitu selama 96 jam dengan efisiensi degradasi sebesar 59,36\%. Hasil perhitungan konsentrasi masing-masing sampel pada variasi waktu kontak disajikan pada Tabel 1.

Tabel 1. Data Hasil Degradasi Zat Warna Acid orange 7

\begin{tabular}{ccc}
\hline $\begin{array}{c}\text { Waktu } \\
\text { Kontak } \\
\text { (jam) }\end{array}$ & $\begin{array}{c}\text { Konsentrasi } \\
\text { awal (ppm) }\end{array}$ & $\begin{array}{c}\text { Konsentrasi } \\
\text { Terdegradasi } \\
(\mathrm{ppm})\end{array}$ \\
\hline 24 & 12,50 & 3,61 \\
48 & 12,50 & 6,15 \\
72 & 12,50 & 6,31 \\
96 & 12,50 & 7,41 \\
120 & 12,50 & 7,94 \\
144 & 12,50 & 7,98 \\
\hline
\end{tabular}

Aktivitas jamur dalam mendegradasi zat warna dipengaruhi oleh lama waktu kontak antara miselium jamur dengan zat warna tersebut (John, 2001). Waktu kontak optimum zat warna ditentukan dari nilai persentase degradasi yang paling besar, yang disajikan pada Gambar 2.

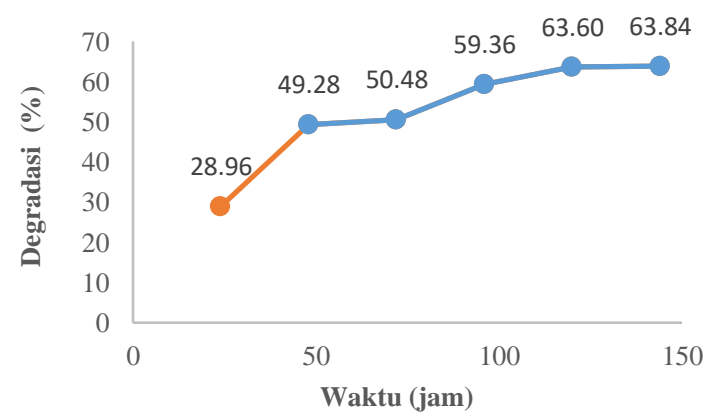

Gambar 2. Grafik degradasi zat warna acid orange 7 pada variasi waktu (jam)

Berdasarkan Gambar 2, dapat diketahui bahwa meningkatnya waktu degradasi menyebabkan meningkatnya persentase degradasi zat warna- Pada waktu kontak 24 jam enzim melakukan fase adaptasi dengan lingkungan sehingga menghasilkan persentase degradasi yang relatif rendah yaitu $28,96 \%$. Setelah fase adaptasi enzim bekerja dengan mendegradasi zat warna, hasil degradasi merupakan nutrisi bagi pertumbuhan miselium jamur. Hal ini menunjukkan, sesuai dengan pernyataan, bahwa jamur 
tiram putih mampu menggunakan zat warna sebagai sumber karbon yang menyebabkan zat warna berkurang atau habis (Tavcar, 2006).

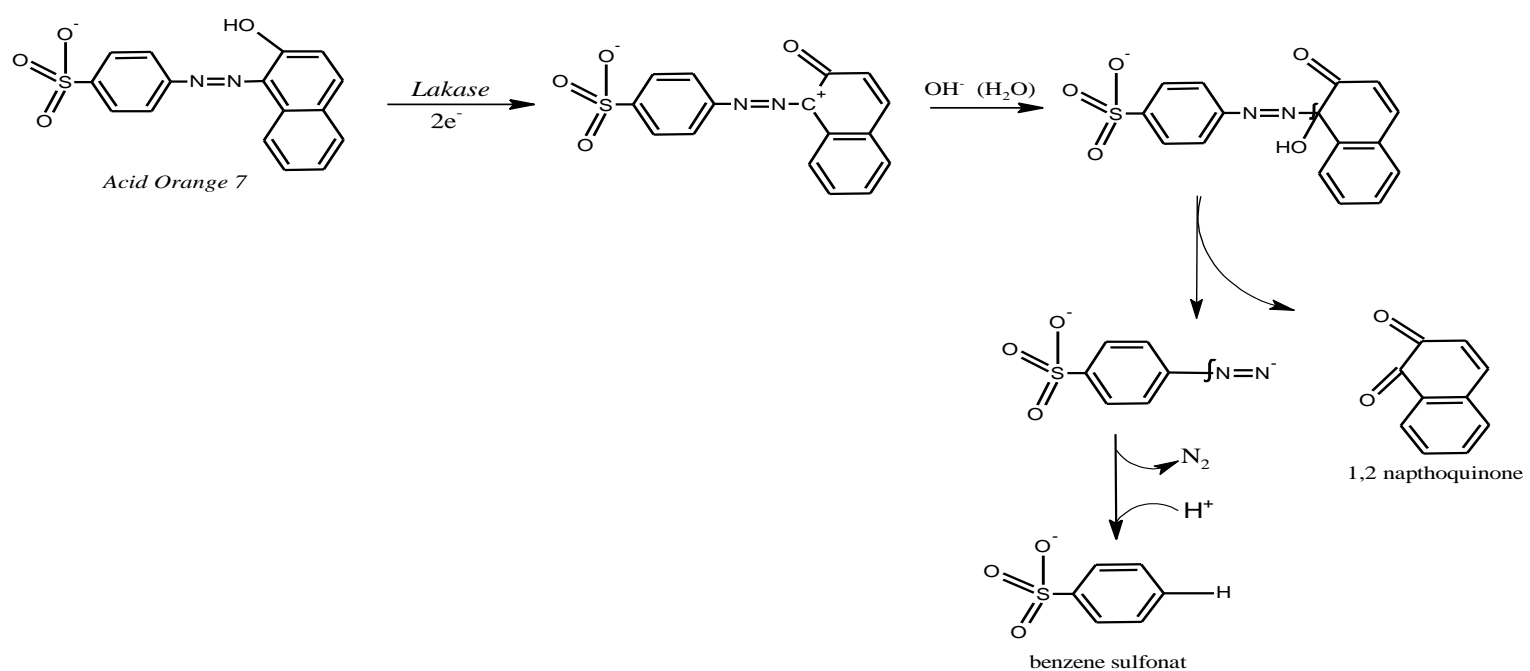

Gambar 4. Ilustrasi degradasi zat warna acid orange 7 (Andrea, et al., 2005)

Reaksi yang terjadi merupakan reaksi oksidasi oleh enzim lakase. Enzim lakase merupakan enzim yang banyak mengandung logam tembaga dan mempunyai kemampuan untuk mengaktifkan enzim, sehingga bagian tertentu dalam enzim mampu mengoksidasi senyawaan fenol.

Lakase mengkonversi senyawaan fenol menjadi quinin radikal dan dengan bantuan oksigen mengubahnya menjadi quinon (Hatakka, 2001). Lakase pada jamur mampu mengoksidasi ikatan azo ($\mathrm{N}=\mathrm{N}-$ ) yang merupakan gugus kromofor menjadi gugus $\mathrm{N}_{2}$ (Yaropolov, et al., 1994). Mekanisme reaksi yang terjadi dapat dilihat pada Gambar 4.

Waktu kontak selama 96 jam merupakan waktu optimum enzim dalam mendegradasi zat warna, hal ini karena

\section{Daftar Pustaka}

Andrea Z., Barbara G., Astrid R. and Artur Cavaco-Paulo. 2005. Degradation of Azo Dyes by Trametes villosa Laccase over Long Periods of Oxidative Conditions. Applied And Environmental Microbiology. 71 (11) : 6711-6718. kemampuan jamur telah mencapai pada titik jenuh penyerapan dan kandungan nutrien yang telah habis yang mengakibatkan zat warna tidak terdegradasi lebih lanjut. Proses degradasi yang terjadi disebabkan karena adanya aktivitas metabolisme dengan sistem enzimatik yang menyebabkan pewarna dimanfaatkan sebagai sumber nutrisi alternatif oleh jamur $P$. ostreatus.

\section{Kesimpulan}

Berdasarkan hasil yang diperoleh, dapat disimpulkan bahwa ekstrak enzim ekstraseluler jamur tiram putih (Pleurotus ostreatus) dapat digunakan untuk mendegradasi zat warna acid orange 7 hingga $59,36 \%$.

Awaludin, R., Darah, I., Ibrahim, C.O and Uyub, A. M., 2001. Decolorization of Commercially Available Synthetic Dyes By TheWhite Rot Fungus Phanerochaete chrysosporium. Journal Fungi and Bactery. 62 : 55 63. 
Chung, K.T., Fulk, G.E. and Andrews, A.W. 1981. Mutagenicity Testing of Some Commonly Used Dyes. Applied and Enviromental Microbiology. 42 (4): 641-648.

Hatakka A. 2001. Biodegradation of lignin. In: Steinbüchel A. Biopolymers. Lignin, Humic Substances and Coal. 1 : 129-180.

John, T. N. 2001. Biological Treatment of a Synthetic Dye Water and an Industrial Textile Wastewater Containing Azo Dye Compounds. Thesis. Virginia Polytechnic Institute and State University.

Katia M.G Machado, C.A Luciana, O Rúbio, Morais, H Luiz, H Santos. 2006. Biodegradation of reactive textile dyes by Basidiomycetous fungi from Brazilian ecosystems. Brazilian Journal Microbiol. 37 :481-487.
Sastrawidana, I D.K., Maryam, S. dan Sukarta, I N. 2012. Perombakan Air Limbah Tekstil Menggunakan Jamur Pendegradasi Kayu Jenis Polyporus Sp Teramobil Pada Serbuk Gergaji Kayu. Jurnal Bumi Lestari. 12 (2).

Tavcar, M. 2006. Biodegradation Of Azo Dye R016 In Different Reactors By Immobilized Irpex Lacteus. Acta Chim Slov. 53 (1) : 338-343.

Ulfi, Aulia., Purnomo, A. S dan Putri, E. M. M., 2014. Biodegradasi Metilen Biru Oleh Jamur Pelapuk Coklat Fomitopsis pincicola. Jurnal Seni Dan Sains. 2 (1) : 1-4.

Yaropolov, A. I, Skorobogatko, O. V, Vartanov SS, Varvolomeyev, S. D. 1994. Catalytic mechanism of laccase. Journal Biochem and Biotechnol. 49 : 257-280. 